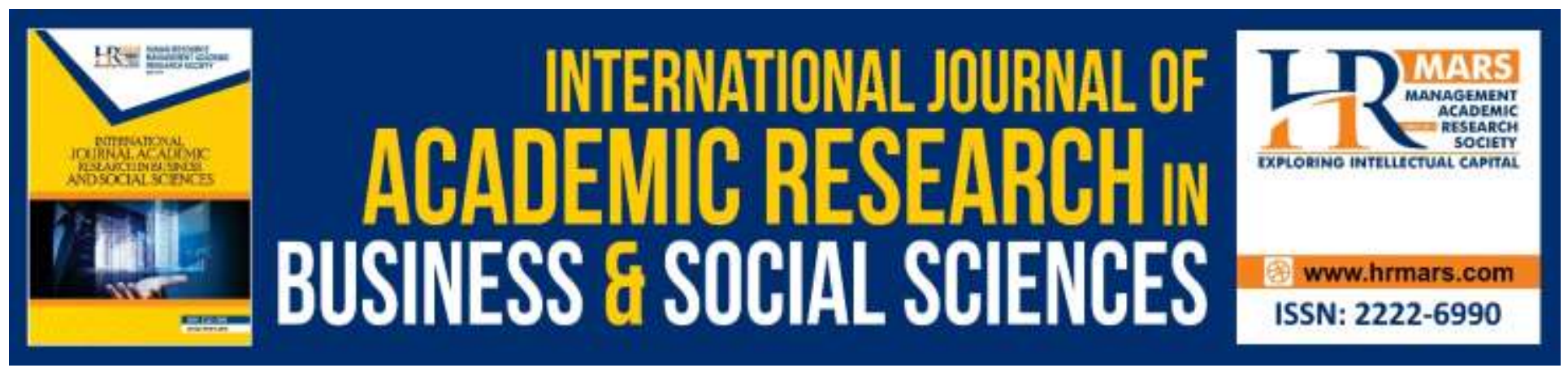

\title{
Reasons for Non-Disclosure of Accountability Practices Information on the Website of Malaysian Local Governments
}

Dayang Hafiza Abang Ahmad, Corina Joseph and Roshima Said

To Link this Article: http://dx.doi.org/10.6007/IJARBSS/v10-i3/7052

DOI:10.6007/IJARBSS/v10-i3/7052

Received: 04 February 2020, Revised: 23 February 2020, Accepted: 13 March 2020

Published Online: 28 March 2020

In-Text Citation: (Ahmad et al., 2020)

To Cite this Article: Ahmad, D. H. A., Joseph, C., \& Said, R. (2020). Reasons for Non-Disclosure of Accountability Practices Information on the Website of Malaysian Local Governments. International Journal of Academic Research in Business and Social Sciences, 10(3), 292-308.

Copyright: (C) 2020 The Author(s)

Published by Human Resource Management Academic Research Society (www.hrmars.com)

This article is published under the Creative Commons Attribution (CC BY 4.0) license. Anyone may reproduce, distribute, translate and create derivative works of this article (for both commercial and non-commercial purposes), subject to full attribution to the original publication and authors. The full terms of this license may be seen at: http://creativecommons.org/licences/by/4.0/legalcode

Vol. 10, No. 3, 2020, Pg. 292 - 308

http://hrmars.com/index.php/pages/detail/IJARBSS

JOURNAL HOMEPAGE

Full Terms \& Conditions of access and use can be found at http://hrmars.com/index.php/pages/detail/publication-ethics 


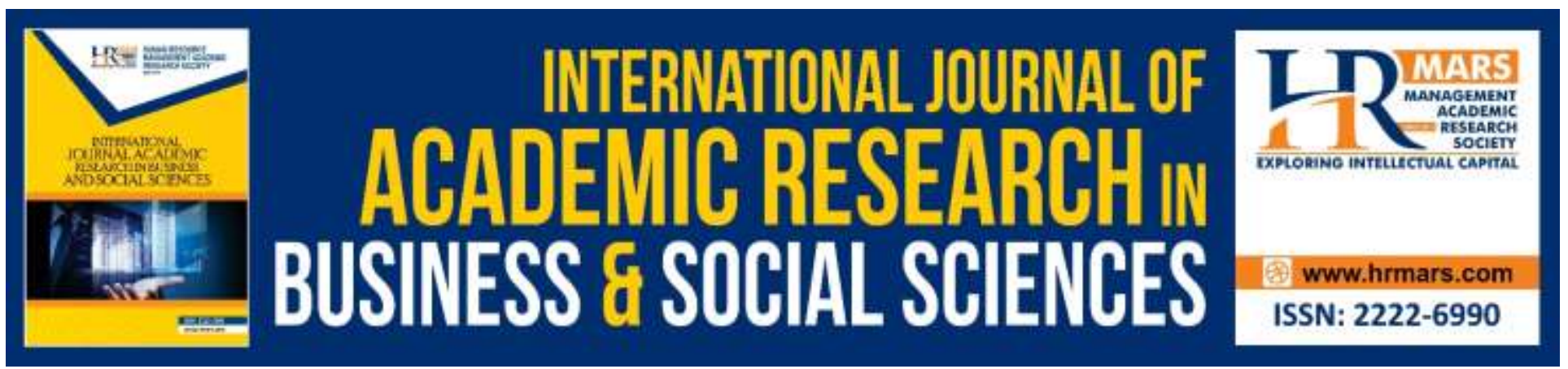

\title{
Reasons for Non-Disclosure of Accountability Practices Information on the Website of Malaysian Local Governments
}

Dayang Hafiza Abang Ahmad' ${ }^{1}$, Corina Joseph ${ }^{2}$ and Roshima Said ${ }^{3}$

${ }^{1}$ PhD in Accountancy candidate, Universiti Teknologi MARA (UiTM), Shah Alam, Malaysia, ${ }^{2}$ Faculty of Accountancy, Universiti Teknologi MARA (UiTM), Sarawak Branch, Malaysia, ${ }^{3}$ Accountancy Department, Universiti Teknologi MARA (UiTM), Kedah Branch, Malaysia

Email: dayanghafizaabgahmad@gmail.com

\begin{abstract}
This paper attempts to explore the reasons for non-disclosure of accountability practices information (API) on the website by selected Malaysian local governments. The behaviours of Malaysian local governments towards non-disclosure of API is explained from the perspective of institutional isomorphism concept. Data collection was carried out through semi structured interviews among officers who are directly or indirectly involved in making decision related to accountability practices and agenda. The analysis of data revealed a greater influence of coercive pressures exerted on the selected local governments' non-disclosure of API on the website. This paper reveals the effect of regulatory regulations, informational control, and behavioural control on the disclosure behaviours of local governments. Contribution of the study to the literature of public sector studies is prominent as it provides an insight into the factors influencing the non-disclosure of API. The findings of this study share useful contributions to the local government organisations to improve the accountability practices and its disclosure.
\end{abstract}

Keywords: Accountability Practices, Isomorphism, Local Government, Non-Disclosure, Website

\section{Introduction}

Local governments in Malaysia receive attention from several groups of stakeholders especially from the public for greater transparency and accountability in providing information. Public sector around the world, including the Malaysian public sector has continuously suffered from inefficient and ineffective administrative system and services delivery since the economic crisis in the United States (US) and the United Kingdom (UK) between 1970s to 1980s (Robinson, 2015). Accordingly, Malaysia has undergone a number of agendas under public sector reform to improve the administrative systems and public services delivery (Mucciarone \& Neilson, 2011). The implementation of public sector reform by Malaysian government to improve transparency and 
INTERNATIONAL JOURNAL OF ACADEMIC RESEARCH IN BUSINESS AND SOCIAL SCIENCES Vol. 10, No. 3, March, 2020, E-ISSN: 2222-6990 @ 2020 HRMARS

accountability which as well enhances the broader administration system is related to the New Public Management (NPM) model. The model linked to four administrative approaches, one of them is the development of information technology (IT) in the delivery of public services (Hood, 1991). The NPM reform has started in the Malaysian public sector aiming to increase the administration's efficiency and effectiveness, including the use of website as a channel for disclosing information.

The delivery of public services is highly associated with the disclosure of information by government organisations especially local governments where they are expected to response to the needs of public for full information (Ling et al., 2018). The desire for a transparent information from the public urges local governments to improve its services delivery through the disclosure of information which helps in increasing public trust. As one of the government tiers, the improvement of local governments' accountability is by contributing to the achievements of accountability of the entire public sector in Malaysia. Given the extensive development of information and communication technology (ICT) as well as digital revolutions, the use of website as a medium for disseminating information is expected to enhance organisations' transparency and accountability (Arpit, 2012). If not enforced, the use of website as medium for disclosure should be encouraged (Ismail \& Abu Bakar, 2011). Among the reform initiatives undertaken by Malaysian government related to local governments ICT are One Stop Centre (OSC) Online for Local Government, Star Rating System on Public Management issued by Malaysian Administration Modernisation and Management Planning Unit (MAMPU), and Open Government Data. Despite these initiatives, accountability of Malaysian public sector is still reported as lacking (Said et al., 2018) and local governments' accountability is yet questionable (John, 2017). In fact, Malaysian public sector is still far from high accountability practices (Toh, 2017).

The lacking of accountability in the Malaysian public sector happens as a result of the increasing corruptions among public officers (Abdul, Yusoff, \& Mohamed, 2019). Corruption matters because it could adversely affect not only local governments, but the entire public sector administrative system. In the local governments, there were 73 officers arrested among 126 cases investigated by the Malaysian Anti-Corruption Commission (MACC) due to corruptions (Suri, 2019). Furthermore, in other government agencies, recent statistic by MACC shows that, in January 2020, 41 public sector officers were arrested for corruptions. This indicates that there is an inadequate mechanism in public sector organisations including local governments that can be used to effectively detect and combat corruption. One way to combat corruptions is by enhancing the accountability practices.

The accountability practices of local governments can be enhanced through disclosure on the website, hence reduces the possibility of corruption. Nevertheless, it is known that the level of disclosure varies across local governments (Tremblay-Boire \& Prakash, 2011). Past literature acknowledged the usefulness of information disclosure to improve the accountability practices of organisations (Do et al., 2012) which eventually minimise corruption (Suri, 2019). Furthermore, the adoption of IT as a mean to improve public services of local governments of Malaysia has been acknowledged by Shahib and Risky (2017). Several prior studies were carried out to investigate the factors and reasons influencing the disclosure of information related to accountability (see for example, Shahib \& Risky, 2017; Abu Bakar, 2013; Akbar, 2012; Tremblay-Boire \& Prakash, 2011; Kluvers \& Tippett, 2010) and some of them reported a low to moderate level of disclosure of the information (for example Abu Bakar, 2013; Akbar, 2012; Tremblay-Boire \& Prakash, 2011). 
Despite the low level of disclosure revealed by prior studies, however, there are very few studies exploring the reasons for non-disclosure of information related to accountability. Among the studies that examined the reasons for non-disclosure of accountability are by Van Belle and Mayhew (2016), Abu Bakar (2013), Akbar (2012). Van Belle and Mayhew (2016) identified three causes for an underdeveloped accountability, namely, key actors, governance arrangement, and accountability practices and its appraisal. the Abu Bakar (2013) had classified the reasons for both disclosure and non-disclosure of accountability information into internal and external forces, while, Akbar (2012) classified it into four major themes, namely, technical, organisational, political and moral. These studies are nonetheless inadequate to explain and provide an in-depth understanding of the nondisclosure of API, particularly on the website by local governments. Therefore, this paper focuses on examining the following research question:

- Why don't selected local governments in Malaysia disclose the accountability practices information (API) on websites?

By answering this question, the empirical evidence of this paper should be able to achieve the following research objective which contributes to the emerging literature on the drivers influencing the non-disclosure of API on websites:

- To investigate the reasons for non-disclosure of API on websites by selected Malaysian local governments.

Due to the unsatisfactory level of disclosure of API revealed by prior studies and limited literature that explain the drivers or reasons for non-disclosure, this paper is motivated to explore and fill in the lacking area of knowledge. Understanding of the possible reasons for non-disclosure allows an identification of the likely actions by local governments to resolve the issue of low disclosure, thus, improve transparency. This paper adopts semi-structured interviews to explore the experiences and opinions from public officials of selected local governments regarding the accountability practices on the website in which the findings contribute not only to the academic literature but also to the local governments and policy makers.

This paper is structured as follows: Section 2 provides an overview of past literature related to this paper; Section 3 presents the theoretical framework used as a basis to explain the findings in this paper; Section 4 discusses the methodology used to answer the question of this paper; Section 5 presents the findings of this paper, supported with selected feedbacks provided by respondents; Section 6 provides an in-depth discussion of the findings; finally, Section 7 concludes the paper where summary of findings, limitation and contributions of this paper are also incorporated.

\section{Literature Review}

The increasing use of accountability concept in diverse disciplines (Lindberg, 2009) shows that the concept is relevant to be continuously explored by scholars. Studies in public sector on the accountability from different aspects such as disclosure practices (Shahib \& Risky, 2017; Abu Bakar, 2013), accountability status assessment (Said et al., 2015), determinants of accountability (Halaby \& Hussainey, 2015) as well as challenges to accountability (Mohamad et al., 2013) have been examined in prior studies. Accountability is an element of good governance and foundation of trust in public sector. Since the 1970s and 1980s crises in the United States (US) and United Kingdom (UK), several issues in public sector such as inefficient and ineffective administrations, increase in fraud and corruption activities, and poor delivery of public services (Gruening, 2001) had been highlighted. The 
issues received attentions from many group of stakeholders because of their continuous occurrences in present days, hence, accountability of public sector is questioned.

Bovens (2007, p.450) defined accountability as "a relationship between an actor and a forum, in which the actor has an obligation to explain and to justify his or her conduct, the forum can pose questions and pass judgement, and the actor may face consequences". In the context of government organisations, accountability refers to the duty of a public officer to perform assigned tasks (Gray and Jenkins, 1993) in compliance with the procedures and to provide the superior with justifications for his or her actions (Moncada, 2009). Cendón (1999) stated that accountability is one aspect of the responsibility that should be viewed as a more comprehensive concept. At the local government level, non-performance of duties by public officers affect the accountability function of local governments which resulting in inefficiency and ineffectiveness of administration and public services delivery of respective local governments.

Local governments' accountability is closely related with the openness of information disclosing by them to the public. One of many ways of exercising accountability is through disclosure of information which is accurate, valid and complete (Pivac et al., 2017). Nor et al. (2019) asserted that disclosure is a form of accountability to the public. Information associated with accountability can be disclosed by means of annual reports, financial reports, web reporting and social media (Arpit, 2012) depending on the context of studies. Local governments are also expected to comply with laws and regulations, community expectation towards accountability and integrity practices, and being transparent in disclosing information. These aspects may influence the level of disclosure or nondisclosure of information by local governments, especially the disclosure on websites which will be exposed to cyber risks such as system failure, human errors, hack, and virus attacks.

There are several factors or drivers that influenced the disclosure of information by organisations recognised in prior studies. For example, audit opinions (Nor et al., 2019; Agustiningsih et al., 2017) and geographical size (Shahib \& Risky, 2017) have influenced on the accountability disclosure of information on the Indonesian local government websites. Besides, populations, political competitions, and size of organisations are among significant factors affecting the disclosure in public sector (Abu Bakar and Saleh, 2015). As government organisations which are always expected by stakeholders to maintain good image and reputation, the visibility of organisations (Cahaya et al., 2016; Tremblay-Boire \& Prakash, 2014) also contributes to the factors. The aforementioned studies carried out to investigate the factors of information disclosure were conducted using quantitative research design that may not represent the opinions of individual personnel within government organisations. The opinions and the views of personnel can be obtained by conducting interviews under qualitative research design.

In contrast to the previously mentioned literature, there are, however, limited studies investigating the influences for non-disclosure of accountability related information by government organisations. Hence, using semi-structured interviews executed on the selected local government organisations, this paper attempts to fill in the gap to identify such factors or drivers.

\section{Theoretical Framework}

The institutional theory has been used to explain the organisational actions, including administrative aspects and management practices. The theory explains that the occurrence of isomorphic change could influence the organisational changes and behaviours. DiMaggio and Powell 
INTERNATIONAL JOURNAL OF ACADEMIC RESEARCH IN BUSINESS AND SOCIAL SCIENCES Vol. 10, No. 3, March, 2020, E-ISSN: 2222-6990 @ 2020 HRMARS

(1983, p.147) asserted that "organisational change occur as the result of processes that make organisations more similar without necessarily making them more efficient". The homogenisation of structure, culture and output of organisations have been referred by DiMaggio and Powell (1983) as isomorphism. The isomorphism can be classified into three types of isomorphic pressure namely coercive, normative and mimetic.

According to DiMaggio and Powell (1983), coercive isomorphism arises as a result of pressures exerted on organisations by other organisations or the cultural expectations of the environment, conveyed through laws and regulations. Whenever higher authorities enacted new regulations, respective organisations are pressured to comply. In this paper, the potential coercive pressures come from the regulatory requirements enforced by higher authorities and top management of an organisation related to non-disclosure of API as well as the classification of information itself.

Normative isomorphism is primarily developed by professionalism and members of organisations where shared norms and values may have gained acceptance within organisations (Ryan \& Purcell, 2004). In this paper, normative isomorphism stems from individual behaviours that may or may not accept certain norms and values i.e. accountability practices, within organisations which eventually reflect the disclosure of API of the entire organisation. Mimetic isomorphism arises due to uncertainty and ambiguity about organisational goals and technologies which lead to imitation of other organisations. In view of this isomorphism, it is irrelevant for this paper as the findings revealed that none of the selected councils mentioned about copying the practices of other organisations.

The application of the institutional isomorphism theory in this paper is in line with the study of Joseph (2011). Joseph (2011) adopted the isomorphism to explain the factors influencing the nondisclosure of sustainability information on websites by Malaysian district councils. The study provides evidence for the presence of coercive pressure resulting from bureaucratic procedures and lack of normative pressures which explained the non-disclosure of sustainability information. Hence, with reference to Joseph (2011), this paper attempts to explore the reasons for non-disclosure of API on websites from the perspective of isomorphism concept.

\section{Methodology}

This paper adopted a qualitative research design where semi-structured interviews were carried out to obtain an in-depth understanding of a phenomena which allowed the respondents to express their opinions on a particular event (Evans, 2017). The interviews were conducted to understand local governments' structures and what drives the non-disclosure of API on websites. Interviews with 12 councils were conducted with officers who directly or indirectly involved in making decisions of the accountability agenda of respective councils. In conducting interviews, it is important for the researcher to identify how much data is needed and when to stop collecting information i.e. identifying the point of saturation. With regards to data saturation, Grady (1998, p.26) asserted that "in interviews, when the researcher begins to hear the same comments again and again, data saturation is being reached...it is then time to stop collecting information and to start analysing what has been collected". Nascimento et al. (2018) suggested that saturation stage is generally reached in 15 interviews, at most. While, according to Creswell $(2007$, p. 76), "[...] there is no set number of cases [...] the researcher chooses no more than four or five cases." 
INTERNATIONAL JOURNAL OF ACADEMIC RESEARCH IN BUSINESS AND SOCIAL SCIENCES

Vol. 10, No. 3, March, 2020, E-ISSN: 2222-6990 C 2020 HRMARS

Prior to interviews, official letters were sent to respective councils requesting the permission from Mayor or Secretary to conduct interviews. The interviewees were selected by the Mayor or the Secretary. Profiles of interviewees were presented in Table 1. After the permission and confirmation were obtained from the respective councils, an interview protocol was provided to the interviewees to give them better ideas of the topic studied.

Table 1. Profiles of Interviewees

\begin{tabular}{|c|c|c|c|c|}
\hline Council & Type & Division & Position & $\begin{array}{c}\text { Length of } \\
\text { service (years) }\end{array}$ \\
\hline $\mathrm{C} 1$ & City & Information Technology & Assistant Director & 14 \\
\hline $\mathrm{C} 2$ & City & Information Technology & $\begin{array}{l}\text { Information Technology } \\
\text { Officer }\end{array}$ & 15 \\
\hline C3 & City & $\begin{array}{l}\text { Information and } \\
\text { Communication } \\
\text { Technology }\end{array}$ & $\begin{array}{l}\text { Information Technology } \\
\text { Assistant }\end{array}$ & 10 \\
\hline $\mathrm{C4}$ & City & $\begin{array}{l}\text { Department of } \\
\text { Management Services }\end{array}$ & Senior Director & 10 \\
\hline $\mathrm{C} 5^{1}$ & Municipal & $\begin{array}{l}\text { Information and } \\
\text { Communication } \\
\text { Technology }\end{array}$ & $\begin{array}{l}\text { Information Technology } \\
\text { Assistant }\end{array}$ & 8 \\
\hline \multirow[t]{2}{*}{ C6 } & \multirow[t]{2}{*}{ Municipal } & Corporate Department & Deputy Director & 10 \\
\hline & & Information Technology & Information Officer & 9 \\
\hline \multirow[t]{2}{*}{$\mathrm{C7}$} & \multirow[t]{2}{*}{ Municipal } & Information Technology & $\begin{array}{l}\text { Information Technology } \\
\text { Director }\end{array}$ & 18 \\
\hline & & Integrity Unit & Integrity Officer & 16 \\
\hline $\mathrm{C} 8$ & Municipal & Management Service & Secretary & 32 \\
\hline \multirow[t]{2}{*}{ C9 } & \multirow[t]{2}{*}{ Municipal } & Management Services & Head of Division & 23 \\
\hline & & $\begin{array}{l}\text { Information and } \\
\text { Communication } \\
\text { Technology }\end{array}$ & $\begin{array}{l}\text { Head of Information } \\
\text { Technology Section }\end{array}$ & 18 \\
\hline C10 & District & $\begin{array}{l}\text { Property Valuation and } \\
\text { Management }\end{array}$ & Tax Assessment Officer & 9 \\
\hline C11 & District & Management Services & Assistant Secretary & 33 \\
\hline \multirow[t]{3}{*}{ C12 } & \multirow[t]{3}{*}{ District } & Management & $\begin{array}{l}\text { Secretary } \\
\text { Deputy Secretary }\end{array}$ & $\begin{array}{l}10 \\
13 \\
\end{array}$ \\
\hline & & Human Resource & $\begin{array}{l}\text { Assistant Human } \\
\text { Resource Officer }\end{array}$ & 23 \\
\hline & & Assessment and Taxation & $\begin{array}{l}\text { Assistant Assessing } \\
\text { Officer }\end{array}$ & 27 \\
\hline
\end{tabular}

${ }^{1}$ During data collection in August 2019, C5 was a municipal council. However, C5 had achieved its City status in September 2019. Therefore, the status of municipal of C5 is maintained for the purpose of reporting. 
INTERNATIONAL JOURNAL OF ACADEMIC RESEARCH IN BUSINESS AND SOCIAL SCIENCES Vol. 10, No. 3, March, 2020, E-ISSN: 2222-6990 @ 2020 HRMARS

Interviews were conducted between August to October 2019 at the selected local governments. The interviews lasted between 45 minutes to one hour and 30 minutes and were audiorecorded with the consent from interviewees. It was complemented by handwritten notes which were taken to capture important points highlighted by the interviewees. The interviews were transcribed in full (Nascimento et al., 2018), precisely and 'word-by-word' (Joseph et al., 2019), and verbatim (Sutton \& Austin, 2015) to ensure the accuracy of interviews transcriptions. Transcribing is a tough process in which spoken words need to be converted into written words for analysis purposes (Sutton \& Austin, 2015).

A thorough reading of interviews transcriptions was carried out after which the analysis of data was performed, in which Miles, Huberman and Saldana (2014) referred analysis as coding. In analysing qualitative data, Miles and Huberman (1994) specified three procedures of data analysis namely data reduction, data display and conclusion drawing and verification. The same procedures were employed by Joseph et al. (2019) in analysing qualitative data related to drivers influencing the implementation of the environmental management system by Malaysian councils. The major phases of data analysis developed by Miles and Huberman (1994) were adopted in this paper.

Data reduction process in this paper involved the reduction of data that appear in the interviews transcriptions from the local councils through data coding and summary as well as removing of irrelevant information. In this process, open data coding is usually used when new concepts were discovered. Data display involved the analysis of assembled and compressed data which permit the drawing of conclusion. At this stage, several reasons that have been coded previously in data reduction process but have similar meanings were combined and summarised into one specific data coding. Drawing conclusions and verification involved the final analysis of data and was performed by cross-checking the data as many times as necessary with the interview transcripts.

\section{Findings}

Based on the institutional isomorphism theory, this study attempts to investigate the reasons for non-disclosure of API on websites by selected local governments. From the analysis of interviews findings, a total of 12 reasons influencing the non-disclosure of API were identified. These reasons were classified into three themes: regulatory requirements (2 reasons), informational control (6 reasons) and behavioural control (4 reasons). Further analysis of the themes pointed to the evidence of coercive (regulatory requirement and information control) and normative isomorphism (behavioural control).

The first theme for the reasons for non-disclosure of API is the regulatory requirement. Government agencies including local governments are bound by regulatory requirements in many aspects of their operation, including disclosure of information on websites. The two reasons classified under the regulatory requirements which restrict the local government to disclose API on the website are: (i) disclosure of API required endorsement from the state government; and (ii) API may be classified under the Official Secrets Act $1972^{2}$. Local governments in Malaysia are governed under

2 The Official Secrets Act 1972 is a law relating to the protection of official secrets primarily intended to protect official matters from falling into the hands of unauthorized person and 
three different Acts for local governments in three different regions namely Local Government Act 1976 for Peninsular Malaysia, Local Government Ordinance 1961 for Sabah, and Local Government Ordinance 1996 for Sarawak. These regulations serve as fundamental references by all related parties including federal, state, and local governments, and other government agencies for administration and monitoring purposes. Additionally, with regards to the disclosure of API on websites, state governments hold a vital role in closely monitoring and ensuring the compliance of related regulations by local governments. Being the regulatory body of a state, state government has full power on local governments under its authority (Joseph, 2010).

In public sector of Malaysia, public officers are prohibited to take or make any documents, record, publish and disclose the document that are classified as 'official secrets' under the Official Secrets Act 1972. Hence, considering the existence of the Act, the disclosure of API on websites by local governments are subjected to the classification of such documents. Otherwise, local councils are allowed to disclose. To illustrate this, the following comment was made by a city council for the restriction imposed by the Official Secrets Act 1972 on all government agencies with regard to disclosure of information:

All councils are bounded by the Official Secrets Act 1972, other circulars and matters involving classified documents - top secrets, secrets, confidential and restricted. If information is classified under these [all regulations previously mentioned], we [council] cannot disclose, not only on the website but also to people outside the council. For classified documents, we [council] had created one application where we [council] direct authorise officers to this application for access. Other than this, we [council] disclose. (IT Officer, C2)

To gain its legitimacy, local governments should comply with the existing regulatory requirement in its context. Violation of the state government's requirements and instructions to implement new regulation causes unfavourable consequences where justifications of such actions should be provided by local governments. Below is an example of the response:

We [council] are responsible for our action. If we [council] do not comply with the requirement [from the state government] and implement new regulation [at local government level], we [council] need to bear with the consequences. In addition, we [council] are required by the Chief Minister Department to send a 'show cause' letter explaining our action. (Head of IT, C9)

The second theme behind the non-disclosure of API which evident the coercive isomorphism is the informational control. It is a system where organisations restrict the processes and procedures of disclosing information (Ivanov, 2010) on websites, especially in terms of types and how much information can be disclosed to people outside the organisations. There are seven reasons identified under the informational control: (i) endorsement from top management, (ii) endorsement from Chief

information which classified as top secret (rahsia besar), secret (rahsia), confidential (sulit), or restricted (terhad). 
INTERNATIONAL JOURNAL OF ACADEMIC RESEARCH IN BUSINESS AND SOCIAL SCIENCES Vol. 10, No. 3, March, 2020, E-ISSN: 2222-6990 @ 2020 HRMARS

Information Officer ( $\mathrm{ClO}$ ), (iii) subject to information supplied by other divisions, (iv) subject to the Standing Committee decision, (v) relevancy of information for website disclosure, and (vi) information concern the public and should not trigger suspicion and uncomfortable among community.

A sound informational control system ensures the accuracy and validity of information, hence improve the quality of information disclosed on the website. Person-in-charge of disclosure of information i.e. the webmaster has crucial role of making sure the information disclosed is of quality. The webmasters are specially appointed by local governments to deal with all IT (Information Technology) related matters including websites maintenance and disclosure of information. However, the duty of webmasters on disclosure of information is restricted by limitation exerted by other divisions or specific officers in a particular local government.

For instance, webmaster is required to obtained approval from top management, respective divisions who own the information and in some cases approval from the $\mathrm{ClO}$ prior to disclosure. Pertaining to supply of information, webmaster has no duties of preparing or supplying information for disclosure but to check that information supplied by other divisions conform to criteria. Additionally, with power authorised by and on behalf of local government, webmaster would disclose approved information on websites.

Each division is 'data holder', hence, they [each division] are also 'data owner'. All divisions prepare and supply the information [about and related to their divisions, because they are the owner of data] to us [IT department]. We [IT department] don't have authority to change the information supplied. After approval from head of respective divisions and $\mathrm{ClO}$ [for certain types of information] was obtained, we [IT department] disclose [on the website if all criteria for disclosure are conformed]. (Senior Director of IT, C4)

In addition to approval by top management, other divisions and $\mathrm{CIO}$, some decisions made at local governments are subjected to the decision of respective Standing Committees which comprise of councillors and top management. In local governments, different committees serve different purposes. The decision of these committees are usually made in the councils' full meetings. For example, a committee for 'Basic Data' which consists of representatives from each department, top management and few councillors is formed to decide on the policy related to 'Basic Data', type of information that can be disclosed, structure of information, as well as monitor the content of information disclosed on websites.

Furthermore, several councils commented on some information which is irrelevant to be disclosed on websites, most probably due to the size and purposes of preparing such information as well as the information is not machine processable. Disclosure of information on websites facilitates the initiatives taken by the Malaysian government to become an open and transparent government. Tauberer (2014) had outlined eight principles for open data including information which is machine processable. Some information which fulfil the criteria for disclosure on websites may not open to the public for access even though the link to such information is provided on websites. Several public officers with authorise power could access to such information through council's website. 
INTERNATIONAL JOURNAL OF ACADEMIC RESEARCH IN BUSINESS AND SOCIAL SCIENCES Vol. 10, No. 3, March, 2020, E-ISSN: 2222-6990 @ 2020 HRMARS

As the closest organisation to the community, local governments should prioritise the welfare of its community including the needs for information. Provision of information should be done in a manner that respect the sentiment of community. Two local councils have mentioned that they disclose information which concern the public but must thoroughly screen the information so that it could not trigger any suspicion and discomfort among public. For instance, information that leads to religious and race issues will be avoided and not permitted for disclosure.

Lastly, reasons for non-disclosure of API on the website that could be themed into behavioural control are: (i) lack of emphasis by top management, (ii) lack of understanding of staff, (iii) individual willingness to accept and practice, and (iv) prefer mediums other than websites. The behavioural control marks the presence of normative isomorphism. Reasons which have been classified under the behavioural control are contributed by the behaviours of individual public officer in a local government which in turn affect the disclosure of API of a particular local government. Lack of emphasis by top management and lack of understanding by staff about accountability practices are among the reasons for non-disclosure of API on websites. In local governments, both top management and staff play crucial role in nurturing the accountability culture within the organisation by practising it themselves. Top management should not expect an individual staff to practise accountability when they do not. On one side, 'show by example' by top management or becoming a role model to the staff may possibly trigger the sense of responsibility of doing the same thing i.e. practising accountability. On another side, staff should make some efforts to understand and obtain knowledge about accountability and consequently practise it.

In my opinion, the most important [to improve accountability] is 'leadership by example'. Top management should show example of practicing accountability to the staff (Assistant Secretary, C11).

In some situations, human behaviours especially an individual staff willingness restricts local governments' efforts to improve accountability. This reason explains the lack of understanding about accountability by staff which is previously mentioned. One should be willing to accept 'accountability' and willing to practise accountability as part of daily routine as public officer without which understanding of accountability practices is lacking.

Accountability is not for specific staff or department [within the council]. All staff [including top management] should know [having knowledge] and understand it [accountability practices] well. We [council] do emphasise the importance of accountability as public officer and we [Human Resource department with top management consent] provide courses and training which [the content] also related to accountability in public sector ... whether individual staff wants and willing to accept and practice [accountability], that is up to them, we [council] control. We [council] can only remind and warn them [the staff] (Assistant Chief Information Officer, (10).

Websites as medium for communication offer many valuable features and benefits including accuracy and validity of information. These features and benefits help local governments to improve 
INTERNATIONAL JOURNAL OF ACADEMIC RESEARCH IN BUSINESS AND SOCIAL SCIENCES Vol. 10, No. 3, March, 2020, E-ISSN: 2222-6990 @ 2020 HRMARS

the delivery of information and increase the efficiency of daily administration and operation through public opinions, feedbacks and complaints. However, due to instantaneous and easy-to-use features of other mediums of communication such as Facebook, Instagram and WhatsApp, many local governments and an individual staff opt for these mediums. For some other local governments, in addition to the disclosure of API on the website, face-to-face meetings with community is still preferred to serve the needs of older generation. For example, council C1 organises 'Town Hall' sessions with a community during which the Mayor and representatives from all departments are present. The sessions facilitate the needs of local community to raise issues and communicate with the council's representatives with the expectation of getting immediate answers and feedbacks.

\section{Discussion}

Local governments' behaviours to disclose or not disclose the API on websites are influenced by several pressures or factors which can be explained using the institutional isomorphism theory. From the interview findings, it reveals that non-disclosure of API on the website of selected councils appeared to be influenced more by coercive pressure exerted on local governments. Two out of three themes classified in the preceding discussion confirm the existence of coercive isomorphism. The findings are consistent with Joseph et al. (2019) where higher authorities order influence the implementation of environmental management system. Similarly, in this context, endorsement from the authorised parties including the state government, top management, head of divisions, the $\mathrm{ClO}$, and Standing Committee, are required prior to actions taken, hence, their non-consent drives on local governments to not disclose the API on websites. This evident the coercive influence from these authorised party have over the non-disclosure of API. The plausible explanation for disapproval from higher authorities is because the information is not for ready for publication or its publication violates the related regulation including the Official Secrets Act 1972.

The violation of the Official Secrets Act 1972 is due to exposure of documents or information classified as top secrets, secrets, confidential or restricted. In relation to this issue, respective authorities and the government of Malaysia would not compromise those who leak any documents or information that could threaten national security (Sulaiman, 2016). Exposure of official secrets by any means will be "punishable with an imprisonment of not less than one year but nor exceeding seven years" (Official Secrets Act 1972, s8), if found guilty. Hence, the non-disclosure by local governments as compliance to the Official Secrets Act 1972 is a result of coercive isomorphism. The finding is in consistency with the findings of Abu Bakar (2013), where the study revealed that organisations did not disclosed the accountability information due to privacy and secrecy of the data. As disclosure is a mechanism used by organisations to communicate with their stakeholders, organisations usually intended to tell the good side of them.

In addition to the pressures exerted by authorised parties and regulations, community as external party, also demand local governments to provide information that concern with their needs and useful for them to make decisions in their daily routine. Hence, the disclosure of information that could create uneasiness and embarrassment among the public should be avoided (Ryan et al., 2002). Community is an informal source of coercive isomorphism where local governments are pressured by social expectation in the community within which the local government is operated. As community is the major stakeholder of local governments, meeting their demands for complete and transparent information indicating the accountability of local governments and it is part of their responsibilities. 
Beside coercive pressures, the behaviours of local governments for their non-disclosure of API on websites are also influenced by normative pressure derived from shared norms and values. Shared norms and values are passed on to each individual within organisations through formal and informal trainings, seminars, and meetings which derived from professions (Joseph \& Taplin, 2012) and should gain acceptance in local governments. The overall performance of an organisation is, at certain degree, depending on the performance of an individual staff. Likewise, the non-disclosure of API by selected local governments happens as a result of indifferent behaviours of individual staff towards accountability practices. The roles of top management and individual staff within local governments are important to ensure the accountability towards different groups of stakeholders can be completely discharged.

Regardless of medium used for disclosure, commitment from each member of an organisation is vital. Based on normative isomorphism, lack of emphasise from top management and lack of understanding from staff signal the absence of shared norms of accountability practices between employers and employees. The absence of shared norms lessens the level of accountability practices of selected local governments, hence, contribute to non-disclosure of API on websites. The findings are consistent with the findings of Minja (2013) in the study of debating the factors that weaken the accountability practices in the public service of Kenyan public sector. Top management should model themselves as highly accountable as possible to the staff which further could evade the possibility of power abuse.

Different individuals may prefer to use different forms of communication channels other than websites. Convenience features of mobile phones are one of the reasons for some local governments' staff, even the head of local governments, opted to use social media such as Facebook, Instagram, and Twitter to disseminate information to the intended users. Social media offers immediate updates of information which can be done any time and at any place at lower costs (Ling et al., 2018). Furthermore, information can reach the intended users faster using social media as compared to websites due to more time spent on social media. According to Clement (2020), global statistics reported that in 2019, an individual spent about 144 minutes (or 2 hours 24 minutes) on average per day on social media. In Malaysia, in 2019, an average of five hours and 47 minutes per day was spent by Malaysian social media users on the platform (Kim, 2019).

\section{Conclusion}

Local governments are held accountable for their actions not only towards the higher government tiers and other government agencies, but ultimately their accountability towards the public especially in the delivery of public services including the provision of information. For certain information and circumstances, it would be better if the information is not disclosed on websites. This paper attempts to investigate the reasons for non-disclosure of accountability practices information on websites by selected local governments. Based on the isomorphism concept, nondisclosure of API on websites is influenced by coercive and normative pressures. Two sources of coercive pressure exerted on local governments are regulatory requirements and informational control. While reasons classified under behavioural control added to normative pressure.

While providing useful insights of the reasons for non-disclosure of API, this paper is subjected to a limitation. This paper was carried out on selected local governments, hence, the findings should 
INTERNATIONAL JOURNAL OF ACADEMIC RESEARCH IN BUSINESS AND SOCIAL SCIENCES Vol. 10, No. 3, March, 2020, E-ISSN: 2222-6990 @ 2020 HRMARS

not be generalised to all local governments in Malaysia. Other local governments that were not included in this paper may have different approaches to the accountability practices on websites.

Despite this limitation, the findings of this paper has its valuable contributions. There are very little literature arguing the reasons for non-disclosure of information. Hence, this paper contributes to the growing literature on the accountability practices in local government organisations, and the use of institutional theory to explain the behaviours of local governments for non-disclosure of API on the website. The findings of this paper are significant for future researchers to identify the factors influencing the non-disclosure of API on websites by local governments. Next, as local governments in Malaysia are operated in similar settings, the findings are useful to other local governments as reference in identifying the reasons for non-disclosure of API in their organisations so as to improve the level of disclosure of API. Other local governments should take into account the aspect that restricts the accountability practices, especially, human behaviours where this study emphasises the importance of top management support and individual commitment to practice accountability which reflect non-disclosure of API on websites.

As limited attention has been given to identify the reasons for non-disclosure of API, this paper makes significant contribution to the theory through the adoption of isomorphism institutional theory in determining the coercive and normative drivers for non-disclosure of API. The nondisclosure of API is driven by coercive pressures that are exerted by higher authorities through the regulated requirements, and the presence of informational control. While behavioural control represents normative pressures. Furthermore, hitherto, this paper is among the first study that revealed the presence of behavioural control and informational control as the drivers for nondisclosure of API. This paper provides an example concerning the application of isomorphism concept on accountability practices. In the context of local governments, the understanding of the behavioural control and informational control enable them to search for a more effective approach of dealing with human (e.g. the staff) and standard of procedures involved in disclosure practices.

\section{References}

Abu Bakar, N. B. (2013). Disclosure of Accountability Information in Public Sector Annual Report: The Case of Malaysian Federal Statutory Bodies. Doctoral dissertation, University of Malaya, Malaysia.

Abu Bakar, N. B., \& Saleh, Z. (2015). Review of Literature on Factors Influencing Public Sector Disclosure: The Way Forward. Asian Journal of Business and Accounting, 8(2), 155-184.

Arpit, B. (2012). E-Government and Social Media as Openness and Anti-Corruption Strategy. Research Journal of Management Sciences, 1(1), 48-52.

Agustiningsih, S. W., Murni, S., \& Putri, G. A. (2017). Audit Findings, Local Government Characteristics, and Local Government Financial Statement Disclosure. Review of Integrative Business and Economics Research, 6(3), 179-187.

Akbar, R. (2012). Performance Measurement and Accountability in Indonesian Local Government. Doctoral thesis, Curtin University, Australia.

Bovens, M. (2007). Analyzing and Assessing Public Accountability. A Conceptual Framework. European Law Journal, 13(4), 447-468.

Cahaya, F. R., Porter, S., \& Tower, G. (2016). Coercive Media Pressures on Indonesian Companies' Labour Communication. Int. J. Critical Accounting, 8(2), 95-117. 
INTERNATIONAL JOURNAL OF ACADEMIC RESEARCH IN BUSINESS AND SOCIAL SCIENCES

Vol. 10, No. 3, March, 2020, E-ISSN: 2222-6990 C 2020 HRMARS

Cendón, A. B. (1999). Accountability and Public Administration: Concepts, Dimensions, Developments in Openness and Transparency in Governance: Challenges and Opportunities. Maastricht, The Netherlands.

Clement, J. (2020). Daily Social Media Usage Worldwide 2012-2019. Retrieved from https://www.statistica.com/statistics/433871/daily-social-media-usage-worldwide/

Creswell, J. W. (2007), Qualitative Inquiry and Research Design: Choosing Among Five Approaches. Thousand Oaks, CA: Sage Publication Inc.

DiMaggio, P. J., \& Powell, W. W. (1983). The Iron Cage Revisited: Institutional Isomorphism and Collective Rationality in Organizational Fields. American Sociological Review, 48(2), 147-160.

Do, S. J., Davey, H., \& Coy, D. (2012). Assessing Accountability of Organisations using the Internet to Report: South Korean Local Government. Journal of Finance and Management in Public Services, 12(1).

Evans, C. (2017). Analysing Semi-Structured Interviews Using Thematic Analysis: Exploring Voluntary Civic Participation Among Adults. SAGE Research Method Dataset, http://dx.doi.org/10.4135/9781526439284

Grady, M. P. (1998). Qualitative and Action Research: A Practitioner Handbook. Bloomington: Phi Delta Kappa Educational Foundation.

Gray, A., \& Jenkins, B. (1993). Code of Accountability in the New Public Sector. Accounting, Auditing \& Accountability Journal, 6(3), 52-67.

Gruening, G. (2001). Origin and Theoretical Basis of New Public Management. International Public Management Journal, 4, 1-25.

Halaby, S. E., \& Hussainey, K. (2015). The Determinants of Social Accountability Disclosure: Evidence from Islamic Banks Around the World. International Journal of Business, http://www.craig.csufresno.edu/ijb/Volumes/Volume\%2020/V203-2.pdf

Hood, C. (1991). A Public Management for All Seasons? Public Administration, 69, 3-19.

Ismail, S., \& Abu Bakar, N. B. (2011). Reporting Practices of Malaysian Public Universities: The Extent of Accountability Disclosure. African Journal of Business Management, 5(15), 6366-6376.

Ivanov, M. (2010). Informational Control and Organizational Design. Journal of Economic Theory, 145, 721-751.

John, K. J. (2017). Demand for Accountability. Retrieved from https://m.malaysiakini.com/columns/387329

Joseph, C. (2010). Sustainability Reporting on Malaysian Local Authority Websites. PhD thesis, Curtin University of Technology, Australia.

Joseph, C. (2011). Factors Influencing the Non-Disclosure of Sustainability Information on Malaysian District Councils' Website Within an Institutional Theory Framework. Social and Management Research Journal, 8(1), 1-22.

Joseph, C., \& Taplin, R. (2012). Local Government Website Sustainability Reporting: A Mimicry Perspective. Social Responsibility Journal, 8(3), 363-372.

Joseph, C., Nichol, E. O., \& Jonathan, L. (2019). Councils' Environment Management System: An Isomorphism Enquiry. Management of Environmental Quality: An International Journal, 30(6), 1314-1330. 
INTERNATIONAL JOURNAL OF ACADEMIC RESEARCH IN BUSINESS AND SOCIAL SCIENCES

Vol. 10, No. 3, March, 2020, E-ISSN: 2222-6990 @ 2020 HRMARS

Kim, H. (2019). Malaysians Spend Almost a Quarter of Their Day on Social Media. Retrieved from https://my.yougov.com/en-my/news/2019/04/30/malaysians-spend-almost-quarter-theirday-social-m/

Kluvers, R., \& Tippett, J. (2010). Mechanisms of Accountability in Local Government. International Journal of Business and Management, 5(7), 46-53.

Lindberg, S. I. (2009). Accountability: The Core Concept and its Subtypes. (Working Paper No. 1). Retrieved from Africa Power and Politics Programme.

Ling, S., Gao, S., \& Liu, W. (2018). The Role of Social Media in Promoting Information Disclosure on Environmental Incidents: An Evolutionary Game Theory Perspective. Sustainability, 10, http://doi:10.3390/su10124372

Miles, M., \& Huberman, A. (1994). Qualitative Data Analysis: An Expanded Sourcebook. Thousand Oaks, CA: SAGE Publications.

Miles, M. B., Huberman, A. M., \& Saldana, J. (2014). Qualitative Data Analysis: A Methods Sourcebook. Edition 3, SAGE Publications, Inc., United States of America.

Minja, D. (2013). Accountability Practice in Kenya's Public Service: Lessons to Guide Service Improvement. International Journal of Business and Management Review, 1(4), 54-63.

Mohamad, M., Othman, I. W., \& Mohamed, A. (2013). Accountability Issues and Challenges: The Scenario for Malaysian Cooperative Movement. International Journal of Economics and Management Engineering, 7(6), 1503-1508.

Moncada, E. (2009). Towards Democratic Policing in Colombia? Institutional Accountability Through Lateral Reform. Comparative Politics, 431-449.

Mucciarone, M. A., \& Neilson, J. (2011). Performance Reporting in the Malaysian Government. Asian Academy of Management Journal of Accounting and Finance. 7(2), 35-77.

Nascimento, L. D. C. N., Souza, T. V. D., Oliveira, I. C. D. S., Moraes, J. R. M. M., Aguiar, R. C. B., \& Silva T. F. (2018). Theoretical Saturation in Qualitative Research: An Experience Report in Interview with Schoolchildren. Rev Bras Enferm, 71(1), 228-233, http://dx.doi.org/10.1590/0034-71672016-0616

Nor, W., Hudaya, M., \& Novriyandana, R. (2019). Financial Statements Disclosure on Indonesian Local Government Websites a Quest of Its Determinant(s). Asian Journal of Accounting Research, 4(1), 112-128.

Official Secrets Act 1972.

Pivac, S., Vuko, T., \& Cular, M. (2017). Analysis of Annual Report Disclosure Quality for Listed Companies in Transition Countries. Economic Research-Ekonomska-Istraživanja, 30(1), 721731.

Robinson, M. (2015). From Old Public Administration to the New Public Service Implications for Public Sector Reform in Developing Countries. Singapore: UNDP Global Centre for Public Service Excellence.

Ryan, C., \& Purcell, B. (2004). Corporate Governance Disclosure by Local Government Authorities. (Working Paper). Queensland University of Technology.

Ryan, C., Stanley, T., \& Nelson, M. (2002). Accountability Disclosures by Queensland Local Government Councils: 1997-1999. Financial Accountability \& Management, 18(3), 261-289.

Said, J., Alam, M. M., \& Abd Aziz, M. A. (2015). Public Accountability System: Empirical Assessment of Public Sector of Malaysia. Asian Journal of Scientific Research, 8(2), 225-236. 
INTERNATIONAL JOURNAL OF ACADEMIC RESEARCH IN BUSINESS AND SOCIAL SCIENCES

Vol. 10, No. 3, March, 2020, E-ISSN: 2222-6990 @ 2020 HRMARS

Said, R., Samad, A. K., Sidek, M. N. Z., Illias, N. F., \& Omar, N. (2018). Corporate Social Responsibility Disclosure Index of Malaysian Shariah-Compliant Companies. Humanomics, https://doi.org/10.1108/IJOES-09-2016-0068

Shahib, H. M., \& Risky, F. R. (2017). Accountability in the Internet Era: A Lesson from Local Governments in Indonesia. Hasanuddin Economics and Business Review, 1(1), 57-74.

Sulaiman, I. (2016). Tiada Kompromi Pembocor Rahsia Kerajaan. Retrieved from http://bharian.com.my/node/128136.

Suri, M. Z. S. (2019). SPRM Terima 1871 Maklumat Babitkan PBT Sejak 2014. Retrieved from https://www.bharian.com.my/berita/kes/2019/12/639498/sprm-terima-1871-maklumatbabitkan-pbt-sejak-2014

Sutton, J., \& Austin, Z. (2015). Qualitative Research: Data Collection, Analysis and Management. The Canadian Journal of Hospital Pharmacy, 68(3), 226-231.

Abdul, S. L. M. M., Yusoff, H., \& Mohamed, N. (2019). Factors that Might Lead to Corruption: A Case Study on Malaysian Government Agency. International Journal of Financial Research, 10(3), 216-229.

Tauberer, J. (2014). Open Government Data Definition: The 8 Principles of Open Government Data. Open Government Data: The Book ( $\left.2^{\text {nd }} E d\right)$. Kindle Edition.

Toh, B. (2017). Accountability Still Lacking in M'sia Despite Progress. Retrieved from http://www.theedgemarkets.com/article/accountability-still-lacking-in-msia-despiteprogress.

Tremblay-Boire, J. \& Prakash. A. (2011). Accountability 2.0: Website Disclosure of Accountability Information by Nonprofits. Presented at the $11^{\text {th }}$ Annual Public Management Research Conference. New York.

Tremblay-Boire, J., \& Prakash, A. (2014). Online Disclosure by U.S. Non-profits. International Society for Third Sector Research, 26, 693-719.

Van Belle, S., \& Mayhew, S. H. (2016). Public Accountability Needs to be Enforced - A Case Study of the Governance Arrangement and Accountability Practices in a Rural Health District in Ghana. BMC Health Services Research, 16, https://doi/ 10.1186/s12913-016-1836-1. 